Ljiljana Stošić Mihajlović1

High School Applied Profesional studies, Vranje

\section{Miloš Nikolić ${ }^{2}$}

Faculty of Business Economics and Entrepreneurship,

Belgrade
SCIENTIFIC REVIEW ARTICLE

DOI:10.5937/ekonomika1704075S

Received October, 10, 2017

Accepted: November, 30, 2017

\title{
SOCIAL ENTREPRENEURSHIP SUPPORTED BY CREATIVE ECONOMY
}

\begin{abstract}
Social entrepreneurship is a multidimensional and dynamic structure that moves between public and private sectors and volunteering. One of the biggest problems facing all countries of the world today is the reduction of unemployment, primarily youth and socially vulnerable categories. With the same problem - the countries of the Western Balkans face, including Serbia. The high unemployment rate of socially vulnerable and young people results in negative implications because they face difficulties in finding a job. Unemployment is an important indicator that has both social and economic dimensions. From an economic perspective, unemployment can be viewed as exploiting the capacity of the workforce. Social entrepreneurship helps create new jobs, develop new skills, the opportunities of unemployed and vulnerable people to participate in society and the economy. The main goal of this paper is to point out the fact that social entrepreneurship is an opportunity to encourage the development of the local community and the national economy. Particular emphasis is on the development of social entrepreneurship of the young, because an effective strategy for preparing young people implies that they are not only educated, but also highly educated with leadership skills that can be raised at an entrepreneurial level and will thus be active creators of the economy in the future, especially emphasizes the potential and contribution of a new - creative economy in the development of social entrepreneurship.
\end{abstract}

Key words: social entrepreneurship, social enterprises, creative economy.

JEL classification: E24, I25, L31

\section{СОЦИЈАЛНО ПРЕДУЗЕТНИШТВО ПОДРЖАНО КРЕАТИВНОМ ЕКОНОМИЈОМ}

\footnotetext{
Апстракт

Социјално предузетништво је мултидимензионална и динамична структура која се креће између јавног и приватног сектора и волонтерства. Један од највећих проблема у којима се данас суочавају све земље света је смањењене

${ }^{1}$ mihajlovicp@ptt.rs

2nikolic2206@gmail.com
} 
запослености, у првом реду младих и социјално рањивих категорија. Са истим проблемом - суочавају се и земље Западног Балкана, међу њима и Србија. Висока стопа незапослености социјално рањивих као и младих људи резултира негативним импликацијама, јер се суочавају са потешкоћама у проналажењу посла. Незапосленост је важан индикатор који има и друштвене и економске димензије. Са економске перспективе, незапосленост се може посматрати као искориштавање капацитета радне снаге. Социјално предузетништво помаже устварању нових радних места, развијању нових вештина, могућности незапослених и угрожених људи да учествују у друштву и економији. Главни циљ овог рада је да укаже на чињеницу да социјално предузетништво представља прилику да би се подстакао развој локалне заједнице и националне економије. Посебан акценат у раду је развоју социјалног предузетништва малдих, јер ефикасна стратегија за припрему младих људи подразумева да не буду само образовани, већ и високо образовани са лидерским вештинама које могу подићи на предузетнички ниво и тиме ће у будућности бити активни креатори економије.У раду се посебно наглашава потенцијал и допринос нове - креативне економије у развоју социјалног предузетништва.

Кључне речи: социјално предузетништво, социјална предузећа, креативна економија.

\section{Introduction}

Serbia, as in the rest of the country in the region, is faced with significant challenges in solving social and economic problems. These problems are numerous, ranging from poverty, youth unemployment, social exclusion, etc. Social and economic problems have a direct impact on the country's progress in interstate integration, and on the other hand, it seems that the current efforts of the Serbian economy do not provide adequate solutions to these problems. As a result, social entrepreneurship, as a way of thinking, is becoming more and more important. Social entrepreneurship, in its basic definition, represents the idea of a combination of innovative methods that entrepreneurs use in order to achieve long-term social change. Social entrepreneurs identify social and economic problems, outline ideas on how to solve them, and implement solutions on a long-term basis. Social entrepreneurship has emerged as a global phenomenon leading a new type of pragmatic, innovative and social activist with vision, seeking social change and social impact througha combination of tools from business practice, social work in order to achieve lasting social change (Nikols, 2006, 2). The aim of this paper emphasizes the need to promote the potential of social entrepreneurship, in particular the work of social entrepreneurs in the field of young entrepreneurs.

\section{Legislation in the field of social entrepreneurship}

The adoption of the Law on Social Entrepreneurship and Employment in Social Enterprises in Serbia is still in the form of a proposal. Although, on several occasions since the beginning of 2017, the adoption of this law was urgently passed by urgent procedure, but that did not happen and, by its very nature, will not be until the end of the 
current year. According to the definition contained in Article 2 of the draft law on social entrepreneurship and employment in social enterprises: "Social entrepreneurship is organized a social activity of public interest that is being done to create new opportunities for solving social, economic and other problems of the hard-working people and their communities, preventing the emergence and elimination of the consequences of social exclusion and the strengthening of social solidarity and cohesion. "In any case, an important step was made by understanding the need to adopt laws that would regulate social entrepreneurship. By adopting the legislative norms, it is possible to better operate the social enterprises for which there is evident need, since sospoiling companies usually differ from "ordinary" in their social role. This is also reflected in the fact that the profit of a social enterprise does not serve to increase the property of the owner, but rather serves for the employment of people who are more likely to come to work or engage in certain social and medical services, education, environmental protection, cultural heritage and other activities in the local community. Chronologically, so far in Serbia there have been several (three) initiatives for the adoption of this law. Government initiatives in terms of legal solutions have had the sole idea that social entrepreneurship is one of the instruments that can solve the big unemployment problem in Serbia. To a large extent, this is impossible, because it is a private initiative that does not necessarily have priority employment. In fact, a better mechanism for the real functioning of the law on social entrepreneurship is to allow owners of social enterprises to have a secure market, less intentions in the form of lower tax rates and taxes, as well as facilitating the employment of identified strata of socially vulnerable categories of people. The available data from the European Movement in Serbia show that currently, on the basis of various legal forms, there are about 400 companies that could carry the "social" epithet. These companies participate in the GDP of Serbia with only $0.2 \%$ and in employment with $0.5 \%$. On the other hand, in the EU social economy, the economy accounts for a total of $11 \%$ and employment of $6.5 \%$.

However, before we analyze in more detail the increase in employment through the establishment of social enterprises, it is actually a matter of what kind of business it is about, who does it and under what conditions, it is necessary to point out another, absurd way of increasing the percentage of employment rate. Namely, in just one year, Serbia lost 76,000 people, partly due to mass emigration, and partly because of the years of negative natural increase. According to official data, compared to 2014, the number of working-age population has decreased by as much as 146,500 people. Since the employment rate is actually the share of employees in the working age population, when this working part of the population is reduced by such massive demographic discharges, the employment rate is automatically increasing. In this way, escaping the country into some better living conditions and a negative birth rate, in fact, becomes a factor in the growth of employment, and if this trend of reducing the number of inhabitants continues (75,000 annually), the results will, albeit absurdly, be "good" on paper only a few years. Interesting is another critical point that relates to 2016. The year when the highest employment growth occurred in people over 65, and among young people between 19 and 25 years. So, it's about people who have acquired the right to a pension, but who can not survive on their income, so they are forced to do something extra. The second one refers to a youth who, instead of being educated in that age, leaves schools to work and help their parents survive. The jobs that they accept are mostly from the informal sector, 
which means poorly paid and insecure, low-skilled jobs, without the right to sick leave, annual leave, legal working hours, without the right to union organization, without the right to absence due to taking the exam, which is denied to them to education, and the like. Therefore, the most part is the old and omlaina, who, instead of a peaceful pension and textbook, forcefully selects minimal paid and risky jobs. These are disenfranchised people who, in an effort to satisfy basic existential needs, accept any jobs that are far below what is called dignified work and which falls under basic and guaranteed human rights. Although exploited and disadvantaged and leased, workers often hear that they are lazy and that they need to be more and more diligent to work, and that the time of safe jobs has passed. It is trying to impose this state of affairs on normal conditions and to get used to such conditions, both uncertain and,uncertain and casual salary. This situation is not good, because a man who is on the verge of existence, whose work is not valued adequately and in constant uncertainty of loss of work and inability to feed his family, is exposed to constant stress and cramp, which endangers his psychophysical health and destroys the family, and therefore and society as a whole. A person who is economically excluded is excluded both socially and politically. He, so trapped in a vicious circle of survival struggle, without basic financial security for himself and his family has no power or time to direct and organize his own company. On the other hand, today, the unemployed person is required to actively seek work, even though there are no jobs, although there are more than one hundred thousand people in one place. In this way, the problem of unemployment is individualized and the responsibility is transferred to the unemployed person, that he is guilty of not having a job, although it is the duty of the state to create economic conditions and to systematically strive for the creation of quality jobs. Instead, we are witnessing that state institutions promote our workers as cheap labor, and the Law on Dual Education further reinforces the foundations of such a policy that nurtures, instead of preventing overarching, i.e. job insecurity.

\section{Enterprise as a basis for social entrepreneurship}

In the historical context, the idea of entrepreneurship existed for hundreds of years, but the fact is that there is no single, generally accepted definition of entrepreneurship. Although French economists introduced the notion of entrepreneurs more than 200 years ago, the term developed over the years in terms of adding new epithets by which the entrepreneur differs from, for example, leaders and managers, and even more in terms of specific skills and characteristics that an entrepreneur must have (what is inherent and what has been learned and learned). These changes have created a strong tradition that reflects the benefits that are present in the entrepreneurial spirit (Dees \& Emerson, 2012, 1-3). So even today, the notion of an entrepreneur to different people means different. It is generally stated, but there is a general consensus that there is a common type of behavior that involves: taking initiatives, organizing and reorganizing social and economic mechanisms to pool resources in innovative ways and accepting risks, uncertainties and / or potential failures (Hisrich, Peters, Shepherd, 2012 , 6). Entrepreneurship provisions have their dynamic and static dimension, and it can justifiably be said that entrepreneurship is a dynamic process of creating incremental wealth. This process is dynamic, and the achieved state of wealth is, as a rule, such that it requires new 
reflections and new entrepreneurial ideas. Wealth is created by a person who takes on the main risks in terms of capital, time and commitment to careers in order to provide value for the product or service. This product or service can (but also does not have to) be new or unique, but an entrepreneur needs to gain added value from obtaining and pooling the necessary skills and resources (Hisrich, Piters \& Shefed 2012,6). These authors define entrepreneurship as a process of creating something new and a key characteristic is the personality of an entrepreneur who devoted enough time and effort to financial, physical and social risks and uncertainties to eventually receive a reward in the form of money, material or personal satisfaction. This provision emphasizes four aspects of entrepreneurial work. First, entrepreneurship means the process of creating something with new value. Creation should have value for both entrepreneurs and buyers. Second, entrepreneurship dedicates commitment to the necessary time and effort. Only those who go through the entrepreneurial process realize how much time and effort should create something new and do something operational. The third aspect of the definition includes awards for entrepreneurs. The most important of these "rewards" is uncertainty, followed by personal satisfaction, but also a material and money fund is also important. And the last aspect of entrepreneurship is the assumption of taking the necessary risks. Since the action takes place in real time, in the conditions of an uncertain future, entrepreneurial action is uncertain. Entrepreneurs must decide to act even under conditions of complete uncertainty about the outcome of this action. Thus, entrepreneurs create changes through their entrepreneurial actions, i.e. entrepreneurial behavior in response to a decision due to uncertainty about the possibility of profit rewards in the form of profit (Hisrich, Peters Shefed 2012,6). Drucker described entrepreneurs and entrepreneurs in the following way: "Entrepreneurs are always looking for change, reacting to change and looking for opportunities." Moreover, Peter Draker (Draker P., Innovation and Entrepreneurship, Practice and Principles, 1996, pp. 41-45) argues that "there is no difference between entrepreneurship in various spheres of social activity." His claim is supported by the fact that production in the spheres of cultural activities , especially in cultural industries, as well as any other production, is subject to economic principles. According to this author, it is crucial that entrepreneurs see opportunities more than the problems of change. $r$ believes that entrepreneurship is a particular feature, either of individuals, of any institution or company, and that people who seek security, certainty, will usually not be good entrepreneurs. But yes, anyone who can face decision making can learn to be an entrepreneur and to act as an entrepreneur. Therefore, entrepreneurship is a type of behavior rather than a personality trait. His foundations lie in concept and theory, not in intuition. Entrepreneurship is neither science nor art, it is primarily practice and is based on the theory of economy and society. The theory sees changes as something normal and healthy. Entrepreneurs see change as a rule and as something healthy, they always look for changes, respond to them and use them as an opportunity. The entrepreneur transfers resources from the sector of low productivity and income to high productivity and income sectors. In addition, entrepreneurs typically innovate. According to him, innovation is a specific instrument of entrepreneurship and it is an action that gives resources to new capacities to create wealth, it creates a resource.On the basis of the above, at first glance, the idea of social entrepreneurship may seem paradoxical. Entrepreneurs are heroes in making profits in private companies. How can social welfare and entrepreneurship be combined? 
The best way is to connect basic concepts - social and entrepreneurial. From a social point of view, entrepreneurs are viewed from a higher perspective (Leadbeater, 2001, 10-13):

- Their ultimate outcome is social: they promote health and well-being;

- Their fixed assets are forms of social capital, networks, trust and cooperation that enable them to access physical and financial capital.

- The founding organizations are socially owned, in the sense that they are not owned by shareholders and do not profit as their main goal. These organizations are social in the sense that they are part of a civil society, not a state.

- Social entrepreneurs are often entrepreneurs who serve the community, trying to regenerate the location, property or neighborhood they are in.

The categories of social entrepreneurship users are numerous. It is usually considered to be the so-called. invisible, i.e. people who for various reasons tend to exercise their rights which, according to the Constitution and on it, are based on legal norms, they belong. That are:

1) Persons eligible for financial compensation, as well as on the basis of training or in the case of unemployment;

2) Persons older than 50 (long-term unemployed);

3) Persons with disabilities (whose percentage of physical disability is determined by a special commission);

4) Persons internally displaced or who have the status of refugees and expelled from the territory of the former Yugoslav republics;

5) Single parents as well as families where spouses are unemployed;

6) Returnees under a readmission agreement;

7) Persons whose imprisonment service expired;

8) Persons who have been proved, legally prosecuted, were victims of human trafficking, violence, exploitation and neglect;

9) Face faced with life problems at the end of the program of withdrawal from psychogenic substances and alcohol;

10) Hard-to-employ persons, such as analgesics and functionally illiterate persons; members of the Roma national minority and other minorities who live in enclaves and who are more difficult to fit into social milieu (eg Goranci living on the slopes of the Shara Mountains - mainly Islamic religions but loyal citizens of Serbia, often referred to by the Serb people as "siptar" ( this word is not in itself poetic, if literally translated from Albanian this word means eagle).In essence, regardless of who can be a user, the same principles must be applied when establishing, organizing and running a social enterprise. These principles are:

1. Respecting the Constitution of guaranteed human rights and dignity;

2. Equality of inclusion in all areas of social life, regardless of the differences between them;

3. Prohibition of discrimination and the right to equality;

4. Performing activities that are not expressly prohibited;

5. Increasing the number of employed and reducing poverty; 
6. Socially responsible business..

According to the aforementioned draft law, the foreseen forms of a social enterprise are: company, entrepreneurial activity, citizens' association, cooperatives and other forms that are not in contradiction with the goals of founding a social enterprise.

Jobs in which a social enterprise can be established can be in different economic areas, such as:

a) Production of material goods and provision of services (eg in the field of social, child and protection of persons with disabilities;

b) Improving science, education and culture, culture, art and health (using traditional and contemporary methods);

c) Preserving the natural environment;

d) Communal activities (collection of secondary raw materials for the so-called river logistics and recycling);

e) Production of energy from renewable energy resources;

f) Agriculture, catering and ethno tourism;

g) Products of old crafts and domestic crafts;

Social entrepreneurs working in the public and private sectors can be profitable, non-profit or hybrid organizational forms (or a combination of everything) for the distribution of social values and the implementation of change. Such ventures can be incorporated in different ways: voluntary organizations, cooperatives and conventional limited liability companies (Nicholls, 2006, 12).

\section{Social entrepreneurship and the problem of unemployment of the younger}

In the previous sections of this paper, there were words about the number and contribution to GDP at the level of Serbia and the EU, and in the world in the social entrepreneurship sector more than 40 million people and over 200 million volunteers are employed. In the world, attention was mainly focused on the application of business and management skills in achieving social outcomes, as non-profit organizations can act in lucrative revenue generating jobs. Some authors (Diza \& Bornstein) associate social entrepreneurship with the non-profit sector, but in the recent years, the number of researchers is increasing that emphasize that the borders between the non-profit and non-profit sector have been erased. More importantly, David Bornstein sees social entrepreneurs as the power of transformation: "people with new ideas," people who identify social problems and are persistent in realizing their vision of solving these problems, people who simply do not accept "no" as a response, and not they give up until they realize their ideas (Bornstein, 2007, 1). The analysis of scientific and practical approaches for defining social entrepreneurship indicates that the basic characteristics of social enterprises relate to the realization of social goals, the realization of social impact and the application of entrepreneurial management, creativity and innovative solutions in solving social problems. Therefore, the best social entrepreneurship may be seen as a multidimensional and dynamic structure that moves between different determinants: between the public, the private and the voluntary sector. In other words, 
social entrepreneurship is defined through two constituent elements: a strategic focus on social impact and an innovative approach to the realization of the mission.

The basic dimensions around which the concept of social entrepreneurship should be developed are: (Prašek\&Novak, 2012, 14)

- Social mission;

- Social innovation;

- Social changes;

- Entrepreneurial spirit;

- Personality development;

In analyzed literature, persons who can deal with social entrepreneurship must first notice the extent of the problem and are ready to learn about social entrepreneurship. One representative list of social issues and problems that modern society faces drastically includes: the elderly, sick and outcast; persons who are dependent or are in the process of withdrawal from the addiction disease; children and young people with special needs; persons with disabilities; discriminated persons; illiterate and persons excluded from information and communication technologies; the lack of energy consciously needed and the production and distribution of energy from renewable sources; endangered environment and health; an increased number of homeless people, especially abandoned children, which is conditioned by poverty; the danger of peace and conflict resolution; poverty, development of rural areas and prevention of further devastation of the village; abuse and trafficking in human beings (especially children); equality and equality before the law (Prašek \& Novak, 2012, 15). Solving these social problems will depend on the conditions of the environment, cultural differences, etc. Over time, new problems can arise, and those who are current become irrelevant.

Bearing in mind the fact that one of the serious problems is unemployment of young people, the question is the trend of unemployed youth in the EU and the Republic of Serbia. The unemployment rate for young people is generally much higher, even double or more than twice as high as the unemployment rate for all ages. As for the total population, the unemployment rate for young people in the EU declined between 2005 and 2007 , reaching a minimum value $(15.1 \%)$ in the first quarter of 2008 . However, the economic crisis that arose after that period hardly hit the young. Namely, in the second quarter of 2008, the unemployment rate had an upward trend, reaching $23.9 \%$ in the first quarter of 2013 , before it was reduced to $19.7 \%$ at the end of 2015 . The rate of youth unemployment in the EU is systematically higher than in the euro area between 2000 and mid-2007. Since then, until the third quarter of 2010, these two rates have been very close.

The high youth unemployment rate reflects the difficulties young people are facing to find a job. However, this does not necessarily mean that a group of unemployed persons between the ages of 15 and 24 is really unemployed because many young people are educated and full time (so they are not part of the labor force used as a nominee for calculating youth unemployment). (Eurostat statistics). As far as Serbia is concerned, the highest unemployment rate is noted for people aged 15-24 and one of the major challenges. Under the current conditions, Serbia creates jobs, with a special focus on young people. As Serbia's strategic commitment to EU membership, then it is legitimate to ascertain what the EU's role in the sector is. Given the fact that all EU member states 
take full responsibility for youth and youth policy, the EU Youth Strategy has been adopted and adopted as a framework for co-operation currently covering the period 2010-2018. According to these strategies, two general objectives have been set (the EU Youth Strategy):

1. Provide more and equal opportunities for young people in the education and labor market.

2. Encourage young people to actively participate in society.

These goals are achieved through a dual approach, which includes:

- Specificity of youth initiative aimed at young people to encourage nonformal learning, participation in volunteer activities, youth work, mobility and information.

- Integration of cross-sectoral initiatives that enable young people to consider in the formulation, implementation and evaluation of policies and activities in other settings with a significant impact on young people, such as education, employment, health and well-being.

The EU Youth Strategy proposes initiatives in 8 areas:

1. Education and science.

2. Employment and Entrepreneurship.

3. Health and well-being.

4. Political participation.

5. Volunteer activities.

6. Social inclusion.

7. The young and the world.Kreativnostikultura.

When the definition of youth entrepreneurship should be given, it is not easy, because the term "entrepreneurship", as we pointed out in the previous exposition, has a multidisciplinary character. Given the fact that the term originates from the French word "entreprendre", which means "do something," literally means that "entrepreneur" is a person who takes certain steps in order to achieve economic benefits. Also, the term "entrepreneur" is used for individuals who establish and run their business. In this context, the expression of youth entrepreneurship includes young people who are engaged in entrepreneurship, that is, they establish and manage their own business. On this basis, the term "young entrepreneur" includes young people who own their own business and those who are self-employed. (From the aspect of gender equality, the term "young entrepreneurs" covers both natural sex.)

If we consider the stages of the entrepreneurial process, the three components of entrepreneurship are different:

1. Attitudes (or perceptions) - reflect the extent to which people value entrepreneurship.

2. Activities - measuring the participation of individuals in different phases of the entrepreneurial process as a result of the identified market opportunities and / or needs.

3. Striving - crucial for identifying the (social) economic impact of entrepreneurship.

What is especially important when it comes to youth entrepreneurship is an analysis of entrepreneurial activity according to age. Most entrepreneurs belong to the 
group of 25-34 and 35-44 years. It is important to mention certain differences observed in different regions. Thus, young entrepreneurs at an early stage in a group of 18 to 24 years are the most represented in the European Union and North America; group of entrepreneurs aged 55-64 in the sub-Saharan Africa region. In the Republic of Serbia, the groups are dominated by groups of 25-35 years, and then groups 35-44 and 18-24 years. In Serbia, there are fewer entrepreneurs aged 18 to 24, compared to other countries, only Slovenia has fewer entrepreneurs from the same age group (GEM 2013, 39). The obtained data point to the need to encourage entrepreneurial education of young people in Serbia.

\section{The need for education for social entrepreneurship in Serbia}

Today, in the most developed economies, the role of entrepreneurship is emphasized as an action-oriented way of thinking and behavior. Last year, as well as the entire next decade in Serbia, was declared the year or the decade of entrepreneurship. In Serbia, entrepreneurship is increasingly being treated as a general way of thinking that is applied in everyday life in almost all areas of work and work. Therefore, increasing attention is paid to education for entrepreneurship from the earliest school days. The aims of such education, which take place at different levels, include:

- First, raising the awareness of the participants in the educational process about the importance and importance of taking responsibility for their destiny (leaving the philosophy of "getting a job" and accepting the philosophy "I am everybody to open a post"), and

- Secondly, the promotion of the development of personal qualities (creativity, understanding of business challenges and opportunities in the environment, risk, flexibility and flexibility, persistence and persistence, commitment to taking action, responsibility for the achieved results, etc.)

These goals are particularly important for the future engagement of each individual. Entrepreneurial education, in the broadest sense, should be treated as a set of knowledge and skills that are necessary for the successful performance and functioning of the market, on the one hand, and, on the other hand, acquiring knowledge and skills to be more competitive on the labor market. In this context, it is crucial to adapt the education system to new needs, with the main focus being a special focus on young people. The development of entrepreneurial thinking and entrepreneurial philosophy can be encouraged in younger generations of school age. At the level of primary schools, the goal of entrepreneurial education is in particular to encourage and recognize certain qualitative characteristics of the person, such as: (creativity, independence, action, orientation, willingness to compete) which can be extremely important in the future in all areas. At this stage, independent and very active forms of learning should be developed. This concept offers the first knowledge of the business world and entrepreneur as a "hero". Educational activity at this level should emphasize "learning through the game", presentation of simple examples from practice, visits to local companies and familiarization with successful examples of entrepreneurship. At the high school level, the development of personal qualities should continue. Entrepreneurship education at this level should include: raising the awareness of students about the importance 
of self-employment as a possible career option (not just to be employed but to be an entrepreneur), "learning through work" (leading micro-business), specific training in order to you know how to start successfully and run a business. At the university level, entrepreneurship education should provide students with the amount and quality of information, knowledge and skills to start a business, the development of the ability to perceive the relevant elements in developing a business plan, and develop skills that are important for identifying and assessing business opportunities and problems and how solve them. The importance of entrepreneurship as a skills acquired in lifelong education is recognized in the European Charter for Small Enterprises, which was adopted by the Council of Europe in 2000. In its "Report on Educational Objectives," the EU Council also points to the intensification of the relationship between educational institutions and businesses, as well as the strengthening of the entrepreneurial spirit through the education and training system (European Commission, 2002). The EU Forum topic: "Training for Entrepreneurship" was held in 2003 in France and recommended the introduction of education for entrepreneurship in the formal education system (from primary schools to universities) in the informal education system and within the enterprise (Entrepreneurship Corporation). EU experts suggest that the education system must be prepared for environmental challenges. Moreover, the concept of entrepreneurship education that will have a long-term component, and whose realization will include a network of professors, teachers and trainers, as well as the broad layers of the population, should be created in practice.

\section{Creativity as the basis for social entrepreneurship and business in the future}

This year it is just over 20 years old that the idea for and the development of the creative economy in general has been launched in Great Britain. The basic philosophy was to define the creative potentials of society, especially traditional creative industries such as music, film and industrial design, as examples of the development of the new economy. Until then, the property is creative - whether in the sphere of culture and art. (Rolling Stons as a music group brought a higher income to British society than some companies from the real sector.) The development of creative industries quickly crossed the Atlantic Ocean and found itself in the agenda of many governments as well as in the interests of the interests of, primarily, American universities, . The process accelerated in the first decade of the XXI century and became global by creating a number of chain effects in the field of research, development and engineering.

The phenomenon of creativity, as input into material production and service delivery, has become the subject of numerous studies and authorial approaches. Creativity has also created new syntagms, such as: creative class, creative capital, creative cities. International organizations, Unctad and Unesco, as United Nations agencies, have contributed to the ideology of creativity today evolving into the concept of a creative economy, which is globally monitored, measured and explored through the labor market and the development of the workforce. Especially in the post-2020 period, the knowledge, innovation and creativity economy is expected to become a key model 
for the development of the western economy. However, in the Third World, creativity has also brought a new striving towards the competitiveness of the national economy, so today China is the world's leading retailer of creative goods, and until recently unknown economies, such as Vietnamese and Nepal, become more competitive in computer services, and software. (Nigeria is the world's third in the film industry, right behind Hollywood and Bolivia.) The South Korean 2013 social and economic development program is based on seven strategies based on a creative economy. They defined the philosophy of national development as "the combination of science and technology with industry, the fusion of culture with industry, market expansion, the creation of new markets and jobs ... because in the very heart of creative economics lie science and IT industry."

Creativity is a cognitive or other mental process, and at the same time creating an original part, solution or idea that has the purpose, association, imagination and combination of known, but often, seemingly incompatible ideas and solutions, or divergent thinking. The creative economy (according to the definition of the Virtual Institute) are those social, but above all the economic activities (industries, industry) in whose products and services creativity is the most important input, the output of which is products and services that are copyrighted and / or intellectual property potential to create a market value chain. Creative industries include creative industries, such as: architecture and interior decoration; marketing and advertising; film and video; radio and TV; computer services; software industry, applications and gaming; photography; publishing and bookkeeping; visual arts; design; performing arts; antique industry; artistic crafts; music industry; research and development activities (R \& D); educational and scientific activities; technology and engineering activities.

Creativity as a property, ie talent and competence is one of the 10 key traits of employees, according to the findings of the World Economic Forum. In a 2015 study of the future of jobs, with a projection for 2020, creativity ranked third in the top 10 skills and knowledge needed for the beginning of the next decade of the 21 st century, which will be marked by digitization, ie automation / robotization of operations. (In the previous research in 2010, it was in tenth place.) Creativity is still considered one of the "most ludicrous" features, since many skills and knowledge have become a substitute for the performance of robots and application software. Of the other features, according to this study, critical thinking and solving complex problems are the most important needs that will be shown at work places in a couple of years. Physical skills in workplaces will become negligible and make up only $4 \%$ of occupational needs after 2020 . The key 10 attributes of entrepreneurs of the future, and thus social entrepreneurship and enterprise, include: cognitive flexibility, negotiation, customer-oriented service, judgment and quick delivery decisions under uncertainty and risk, emotional intelligence, coordination with others, and human rights management.

\section{Conclusion}

Social entrepreneurship and the social economy are continually developing over the past several decades, not only in developed countries, but in developing countries. Social entrepreneurship as an organizational form has been recognized and recognized 
in many countries because it deals with the identification and resolution of socioeconomic problems, such as youth unemployment, poverty reduction, social exclusion, environmental protection, energy supply from renewable sources. Social entrepreneurship can be viewed as a clue or as a bridge between the public and the private sector, through the identification of social problems, first in local communities, undertaking entrepreneurial initiatives to solve them, of course with respect to the principles that apply in the social sector, in order to improve " quality of life ". Bearing in mind the fact that young people are the foundation of society, on the one hand and on the other hand, a high percentage of youth unemployment, the need to encourage the development of youth entrepreneurship in Serbia is evident. In order to achieve growth and development and create new jobs, appropriate approaches to education are required. In that sense, it is commendable the introduction of a dual education form into our education system. Because, it must be emphasized and recognized that the education of the 21 st century is the cornerstone of competitiveness, as well as survival in contemporary and future insecure and increasingly uncertain conditions of business. Economic success is based on the continuous use of intangible assets, such as knowledge, skills and innovation potential. Therefore, it must be handled according to the requirements of the future, where the only change is certain. Every aspect of the education system, starting from primary, secondary and higher education, but also non-formal education - should be so designed to prepare and train people with the necessary skills of the 21 st century - they simply have to be competitive. "Educated" in the 21 st century means that it is a person who knows how to solve problems that develop critical thinking, which is creative, communicating effectively, ready to work in teams, to create for themselves in the organization, the local community, the state and society place of residence and work.

\section{References}

Bornstein, D. (2007). How to Change the World: Social Entrepreneurs and the Power of New ideas, Oxford University Press.

Draker, P. (1996). Inovacije i preduzetništvo, praksa i principi, PS „Grmeč“, Beograd, $\operatorname{str} 43$.

regory D., \& Emerson, J. (2012). Peter Economy, Enterprising Nonprofits: A Toolkit for Social Entrepreneurs, John Willey\& Sons.

Leadbeater, C. (2001). The Rise of the Social Entrepreneur, Demos, London.

Hisrič R., Piters M.,\&Šefed D. (2012). Pretpriemaštvo, ARS Lamina, Skopje.

Nicholls, A. (2006). Social Entrepreneurship, New Models of Sustainable Social Change, Oxford University Press.

Web site:

http://ec.europa.eu/eurostat/statistics-explained/index.php/Unemployment_statistics , http://ec.europa.eu/youth/policy/youth_strategy/empl_entrepreneurship_en.htm ,

Anketazarabotnasila 2015 godina, DržavenZavodzaStatistikaR. Makedonija http:// www.stat.gov.mk/Publikacii/2.4.16.02.pdf, 
http://www.parlament.gov.rs/upload/archive/files/lat/pdf/predlozi_zakona/168813Lat.pdf,

European Commission-Enterprise Directorate-General, Final Report of the Expert Group "Best Procedure"- Project on the Education and Training for Entrepreneurship, Brussels, November 2002, http://europa.eu.int/comm/ enterprise/enterpreneurshi . 